\title{
Alternative grazing fee formula impacts on representative public land ranches
}

\author{
DAVID P. ANDERSON, JAMES W. RICHARDSON, RONALD D. KNUTSON, JERRY \\ C. NAMKEN, THOMAS R. HARRIS, WILLIAM O. CHAMPNEY, THOMAS R. MAC- \\ DIARMID, AND ANDREW B. MARSHALL
}

\begin{abstract}
Authors are research associate, prafessor, professor, and former post-doctoral associate, Agricultural Economics Department, Texas A\&M University, respectively; professor, professor, research associate, and former research associate Agricultural Economics Department University of Nevada, Reno, respectively.
\end{abstract}

\begin{abstract}
The Farm Level Income Tax and Policy Simulation Model (FLIPSIM) was used to evaluate and quantify the impacts of alternative grazing fee formulas, discussed in the 1986 Grazing Review and Evaluation and its recent update. Economic viability (level of income and risk) was estimated for 4 representative ranches that lease public range lands in the western United States. Average annual net cash income is projected to be positive over the 1992-97 planning horizon although income is projected to decline for the first 4 years as cattle prices weaken. A verage annual net cash income under the alternative grazing fee formulas falls by as much as 37\% relative to the current Public Rangelands Improvement Act formula for all of the ranches studied. Real net worth of each ranch declines as much as $22 \%$ over the study period under the highest alternative grazing fee.
\end{abstract}

Key Words: grazing fee, public lands, simulation, economic viability

There are approximately 108 million hectares of public lands managed by the Bureau of Land Management (BLM) and Forest Service (FS) in 16 western states. These public lands are divided into some 31,000 grazing allotments which represent approximately 16.7 million Animal Unit Months (AUM) (USGAO 1991, USDI 1991). The history of grazing fees has been well documented by Dutton (1953) and others. The current formula for establishing federal grazing fees was specified in the Public Range Improvement Act of 1978 (PRIA).

Grazing fee price levels have always been controversial and have recently come under scrutiny again. In 1991, the U.S. General Accounting Office (GAO) reviewed the Public Rangelands Improvement Act formula (hereafter referred to as the current formula) and reported that the "current formula keeps grazing fees low." The report summarized several alternative objectives the grazing fee formula was expected to meet. Half of the criteria discussed related directly to the fee's impact on the economic viability of ranching. It is clear that higher grazing fees will negatively affect farm and ranch incomes. The levels of these impacts are important considerations in developing and implementing new policies.

The 1986 Grazing Fee Review and Evaluation, hereinafter referred to as the 1986 USDA/USDI study, jointly done by the U.S. Department of Agriculture (USDA) and Interior (USDI) evaluated 5 alternative grazing fee formulas. Their study included an analysis of the impacts of alternative grazing fee levels on ranch

Manuscript accepted 6 May 1993. income. The analysis aggregated USDA budget data for 1982 to develop an average cattle and sheep ranch for each state with Forest Service and Bureau of Land Management grazing. Their results indicated that ranches could cover their cash production costs in the short run with a $\$ 5.00$ per AUM grazing fee. When total costs were considered using a $\$ 5.00$ per AUM fee, the cattle operation in each state had negative returns per cow.

The purpose of this study is to further quantify the impacts of alternative grazing fees on the economic viability (level of income and risk) of ranches leasing public range lands in the Western United States. Four representative ranch operations are simulated using the Farm Level Income Tax and Policy Simulation Model (FLIPSIM). Each ranch is simulated for the years 1992-1997 under the current Public Rangelands Improvement Act formula and 4 other grazing fee formulas discussed in the 1991 GAO study.

\section{Methods}

The Farm Level Income Tax and Policy Simulation Model is a Monte Carlo simulation model developed by Richardson and Nixon (1986). The model has been used for numerous farm level policy and technology analyses (e.g., Richardson and Nixon 1982, Grant et al. 1984, Richardson and Nixon 1984, Richardson and Smith 1985, Smith et al. 1985, Duffy et al. 1986, U.S. Congress 1986, Lemieux and Richardson 1989) and is capable of simulating representative ranch operations under alternative policies and management scenarios.

Analyzing the consequences of alternative federal grazing fees on the economic viability of a representative ranch involves several steps. First, data for the representative ranch under current conditions must be developed and the Farm Level Income Tax and Policy Simulation Model must be validated for the ranch. Second, modifications to the base ranch's input/output coefficients must be made for each fee change to be analyzed. Third, projections for livestock prices, forage prices, and macroeconomic variables (interest and inflation rates) are merged with the ranch's data. By changing the grazing fee, the model can be used to analyze an array of fee formulas for each ranch. Changes in the economic viability of the ranch under the alternative formulas can be used to assess the long-run impacts of the alternative formulas.

The economic activity on each representative ranch was simulated over a 6-year (1992-97) planning horizon. The planning horizon was simulated 100 times (iterations). For each iteration, the model randomly selected prices for sheep, cattle, and feedstuffs based on the average annual prices in the 1992 Food and Agricul- 
Table 1. Price, Cost, and Macroeconomic Projections used for Alternative Grazing Fee Analysis, 1992-97.

\begin{tabular}{|c|c|c|c|c|c|c|}
\hline & 1992 & 1993 & 1994 & 1995 & 1996 & 1997 \\
\hline $\begin{array}{l}\text { Cattle: }(\$ / \mathbf{k g}) \\
\text { Steer }(272-363 \mathrm{~kg}) \\
\text { Cow }\end{array}$ & $\begin{array}{l}.4047 \\
.2340\end{array}$ & $\begin{array}{l}.3952 \\
.2302\end{array}$ & $\begin{array}{l}.3879 \\
.2148\end{array}$ & $\begin{array}{l}.3803 \\
.1988\end{array}$ & $\begin{array}{l}.3663 \\
.2017\end{array}$ & $\begin{array}{l}.3694 \\
.2121\end{array}$ \\
\hline $\begin{array}{l}\text { Sheep prices: }(\$ / \mathrm{kg}) \\
\text { Feeder lamb } \\
\text { Ewe }\end{array}$ & $\begin{array}{l}.2530 \\
.1317\end{array}$ & $\begin{array}{l}.2513 \\
.1317\end{array}$ & $\begin{array}{l}.2481 \\
.1317\end{array}$ & $\begin{array}{l}.2481 \\
.1317\end{array}$ & $\begin{array}{l}.2481 \\
.1317\end{array}$ & $\begin{array}{l}.2481 \\
.1317\end{array}$ \\
\hline Wool price $(\$ / \mathbf{k g})$ & .5448 & .5448 & .5675 & .5902 & .5902 & .5902 \\
\hline Purchased feed index (\%) & 1.16 & 2.40 & 2.68 & 3.08 & 3.32 & 3.36 \\
\hline Producers price index (\%) & 1.53 & 3.57 & 4.25 & 3.82 & 4.41 & 4.62 \\
\hline $\begin{array}{l}\text { Consumer price index }(\%) \\
\text { Interest rate on intermediate } \\
\text { Term debt }(\%)\end{array}$ & 2.51 & 3.24 & 3.75 & 4.09 & 4.71 & 5.08 \\
\hline
\end{tabular}

Source: FAPRI, January, 1992 Baseline, and Penson, 1992.

tural Policy Research Institute baseline and the U.S. Agriculture/General Equilibrium Model baseline (Penson 1992) and the historical probability distributions for these variables. Weaning weights were selected at random each year based on historical probability distributions for these variables on each representative ranch. In this manner, the model incorporated the market, weather, and livestock production (rate of gain) risk faced by ranchers. The random number generation process used in the model insured that each ranch experienced the same weather and market risk across all grazing fee scenarios. Thus, the economic differences between scenarios is due solely to the alternative grazing fees.

Risk associated with the federal grazing fee rate is incorporated into the model using the grazing fee formulas and randomly generated forage and beef cattle prices having the same frequency and variability as observed in the past. All of the grazing fee formulas evaluated either included a forage value index and a beef cattle price index, or simply a forage value index. The Farm Level Income Tax and Policy Simulation Model's randomly generated prices for hay and Omaha fat steers were used as inputs in regression equations to project the forage value index and beef cattle index, respectively, in the grazing fee formulas. Utilizing the econometric linkage between the forage and beef cattle prices and their associated indices, the historical variability in these indices was projected and incorporated into the farm level model, and thus into the analysis of alternative grazing fee formulas.

The results of the 100 iteration analyses constituted an estimate of the probability distribution for net cash income. Average net cash income for the alternative grazing fee formulas can be compared to determine the relative impact of the formulas on the profitability of western ranches. The variability in net cash income across scenarios can be compared using the coefficient of variation for net cash income. A ratio of the coefficient of variation for average net cash incomes for the alternative grazing fee formulas and the coefficient of variation for the current formula is reported for each alternative fee as a measure of the relative change in risk from the current formula.

Table 1 contains selected price, cost, and macroeconomic projections used in the analysis. These projections are developed by a U.S. macroeconomic sector model and by an agricultural sector model. The U.S. sector model is an econometric model that accounts for changes in the world economic situation as well as crop sector changes, such as corn supply and price changes, in the U.S. beef industry. The cattle price projections in Table 1 include the effects of feed grain situation changes in the future. The steer price projections follow a cattle price cycle bottoming out in 1996. The projected inflation rate on production costs (PPI) remains around $4 \%$ throughout the $1992-97$ period.

\section{Alternative Federal Grazing Fee Formulas}

The alternative grazing fee formulas analyzed are those initially developed in the 1986 USDA/USDI study and reviewed the 1991 GAO study:

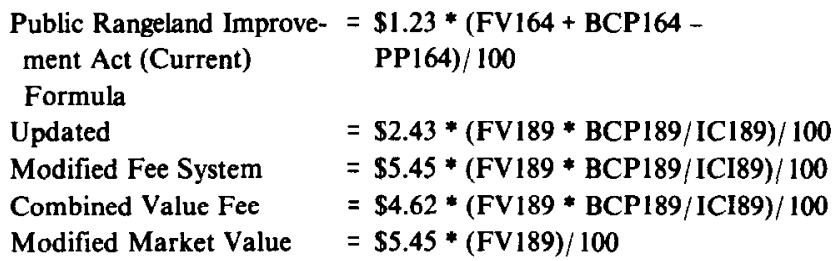

While it is likely that none of these formulas will actually be used, they indicate fee levels that may be charged. The results discussed hold for the impacts of any fee around these levels. The results can be interpreted as the impacts of a fee level not just a particular formula. The average fee level for each formula over the planning horizon is contained in Table 2.

Table 2. Projected federal grazing fees for PRIA and alternative federal grazing fee formulas, assuming 1989-1990 = base for indices used in alternative formulas, 1990-2000.

\begin{tabular}{|c|c|c|c|c|c|}
\hline $\begin{array}{l}\text { Fee } \\
\text { year }\end{array}$ & PRIA & $\begin{array}{c}\text { Updated } \\
\text { PRIA }\end{array}$ & $\begin{array}{l}\text { Modified } \\
\text { PRIA }\end{array}$ & $\begin{array}{l}\text { Combined } \\
\text { value fee } \\
\text { system }\end{array}$ & $\begin{array}{c}\text { Modified } \\
\text { market } \\
\text { value }\end{array}$ \\
\hline & \multicolumn{5}{|c|}{$\ldots \ldots(\$ /$ AUM $) \cdots \ldots$} \\
\hline 1990 & $1.81^{1}$ & 2.33 & 5.23 & 4.43 & 5.45 \\
\hline 1991 & $1.96^{1}$ & 2.53 & 5.67 & 4.81 & 5.45 \\
\hline 1992 & $1.92^{1}$ & 2.73 & 6.11 & 5.19 & 6.00 \\
\hline 1993 & 1.44 & 2.02 & 4.51 & 3.85 & 4.80 \\
\hline 1994 & 1.35 & 1.98 & 4.44 & 3.76 & 4.91 \\
\hline 1995 & 1.35 & 1.90 & 4.28 & 3.62 & 5.01 \\
\hline 1996 & 1.35 & 1.80 & 4.04 & 3.43 & 5.07 \\
\hline 1997 & 1.35 & 1.76 & 3.94 & 3.34 & 5.01 \\
\hline Average & 1.57 & 2.13 & 4.78 & 4.05 & 5.21 \\
\hline
\end{tabular}

'Actual values announced by USD $\Lambda$ and USDI for grazing federal range lands.

The Food and Agricultural Policy Research Institute's January 1992 Baseline projections of cattle and hay prices and inflation rates for inputs (see Table 1) were used to project the federal grazing fees for the alternative formulas. Base values for the 4 alternative grazing fee formulas to the current formula $(\$ 2.43$, $\$ 5.45$, and \$4.62) were updated using indices for 1989-90 (Knutson et al. 1991). Based on the Food and Agricultural Policy Research Institute's projected prices and cost indices, grazing fees for all 5 formulas are projected to decline from 1992 through 1997 (Table 2). Grazing fees for the current formula reach the floor of $\$ 1.35 / A U M$ by 1994 and remain at that level due largely to lower cattle prices. The other formulas also result in lower fees after 1992, reflecting lower cattle prices and higher input costs. Another factor in the projected lower grazing fees is the Food and Agricultural Policy Research Institute's projection of lower hay prices caused by much of the Conservation Reserve Program land being used to produce hay beginning in 1995 .

\section{Panel Ranch Development}

The data used to describe the representative ranches used for the analysis were developed using the panel ranch process. An exten- 
sion farm and ranch management specialist in each state selects the primary production area of the state. The county agent in the primary production area selects producer participants. Each panel consists of 5 to 6 ranchers. These ranchers represent above-average management using sound, accepted production and management practices. Using a questionnaire designed to gather all relevant information to describe the ranch, panel members develop consensus values which represent a typical ranch. Each panel member provides a 10-year livestock production history that is used to incorporate weather/weaning weight risk into the ranch simulations. Data from the panel are processed and mailed to the panel. A conference call is held within a few weeks of the meeting to review the panel's data to insure they were interpreted correctly. Pro forma balance sheets, income statements, cash flow, and livestock summary pages are sent to the panel. A conference call is held to validate the Farm Level Income Tax and Policy Simulation Model's ability to simulate the farm. If changes in the panel's data are necessary, the data are modified, the ranch is simulated, and new pro forma summary sheets are mailed for a conference call. The process is repeated until the panel is confident that the Farm Level Income Tax and Policy Simulation Model accurately depicts the typical ranching operation in their area.

\section{Characteristics of Representative Ranches}

The Chaves County panel ranch, located in southeastern New Mexico, has 2,000 ewes and 100 cows (Table 3). The panel ranch grazes 643 animal units on 11,664 ha of rangeland, of which 6,480 ha are on federal land, 2,074 ha are on state land, and 3,110 ha are owned. The ranch's annual grazing on federal rangeland accounts for $358 \mathrm{AUs}$ and at $\$ 1.92 / \mathrm{AUM}$, the annual lease cost is $\$ 8,248$. The stocking rate is 18.1 ha per $A U$ on federal rangeland and 18.2 ha per $A U$ on owned, state, and private leased rangeland. The land and improvements (buildings, fences, houses, corrals, and water systems) were valued at $\$ 750,000$ by the producer panel. The initial value of all livestock on the ranch estimated $\$ 225,000$. A more complete description of these representative ranches can be found in Knutson et al. (1992).

The Eastern Wyoming shed lambing ranch consists of 2,000 ewes (Table 3). The ranch grazes 6,075 ha, of which 1,823 ha are leased from the federal government, 3,038 ha are owned, and 1,778 ha are leased from state and private sources. The ranch raises alfalfa hay (61 ha) and oats ( $8 \mathrm{ha}$ ) to provide supplemental feed to the sheep and oat straw for the shed lambing activities. The total annual federal grazing cost (\$795) is low because the shed lambing ranch only depends on federal grazing land for $8 \%$ of its $\mathrm{AU}$ needs. This low percentage reflects the limited availability of federal lands in the area where shed lambing operations are located more than the economics associated with federal grazing lands. The stocking rate for federal grazing lands, however, is about 36 ha per $\mathrm{AU}$ compared to an average of 12.4 ha per $\mathrm{AU}$ on owned land, state, and private leased rangeland. For the shed lambing ranch, the average lease cost for state and private land is $\$ 5.72 / A U M$. In this area, the private leased land is high quality mountain pastures used during the summer months, whereas federal rangeland is broken land with little grazing value.

Table 3. Characteristics of 4 representative ranches in New Mexico, Wyoming, Montana, and Nevada.

\begin{tabular}{|c|c|c|c|c|}
\hline & $\begin{array}{l}\text { Southeastern New Mexico } \\
\text { sheep and cattle ranch }\end{array}$ & $\begin{array}{l}\text { Eastern Wyoming } \\
\text { shed lambing ranch }\end{array}$ & $\begin{array}{l}\text { Southeastern Montana } \\
\text { cattle ranch }\end{array}$ & $\begin{array}{l}\text { Northwest Nevada } \\
\text { cattle ranch }\end{array}$ \\
\hline Total animal units (AUs) & 643 & 442 & 483 & 1,740 \\
\hline Federal animal units leased (AU) & 358 & 34.5 & 112.5 & 842 \\
\hline \multicolumn{5}{|l|}{ Sheep } \\
\hline Ewes (no.) & 2,000 & 2,000 & - & - \\
\hline Replacements (no.) & 450 & 450 & - & - \\
\hline Rams (no.) & 60 & 60 & - & - \\
\hline \multicolumn{5}{|l|}{ Cattle } \\
\hline Cows (no.) & 100 & - & 400 & 1,450 \\
\hline Replacements (no.) & 15 & - & 58 & 200 \\
\hline Bulls (no.) & 9 & - & 18 & 90 \\
\hline Hectares owned & 3,110 & 3,038 & 5,670 & 2,349 \\
\hline \multicolumn{5}{|l|}{ Hectares leased } \\
\hline Federal & 6,480 & 1,260 & 1,823 & - \\
\hline State and others & 2,074 & 1,778 & 608 & - \\
\hline Total & 11,664 & 6,076 & 8,101 & 2,349 \\
\hline \multicolumn{5}{|l|}{ Annual land lease costs } \\
\hline Federal @ \$1.92/AUM (\$) & 8,248 & 795 & 2,592 & 19,399 \\
\hline State and others $(\$)$ & 3,090 & 9,855 & 1,500 & - \\
\hline Total $(\$)$ & 10,553 & 10,605 & 3,940 & 19,399 \\
\hline \multicolumn{5}{|l|}{ Assets } \\
\hline Land and improvements $(\$)$ & 750,000 & 500,000 & 700,000 & $1,336,000$ \\
\hline Livestock (\$) & 225,800 & 178,100 & 341,900 & 972,100 \\
\hline Machinery (\$) & 68,100 & 85,800 & 93,000 & 192,200 \\
\hline Total $(\mathbf{( \$ )}$ & $1,043,900$ & 763,900 & $1,134,900$ & $2,500,300$ \\
\hline Long term debt/asset ratio (\%) & 5 & 5 & 5 & 5 \\
\hline \multicolumn{5}{|l|}{ Efficiency measures: } \\
\hline Calf crop weaned $(\%)$ & 96 & - & 90 & 76 \\
\hline Lamb crop weaned (\%) & 90 & 125 & - & - \\
\hline \multicolumn{5}{|l|}{ Calf sale weight: } \\
\hline Steer $(\mathbf{k g})$ & 227.0 & - & 227.0 & 227.0 \\
\hline Heifer $(\mathrm{kg})$ & 181.6 & - & 217.9 & 204.3 \\
\hline \multicolumn{5}{|l|}{ Lamb sale weight: } \\
\hline Ewe lambs (kg) & 33.14 & 43.13 & - & - \\
\hline Ram lambs (kg) & 36.32 & 43.13 & - & - \\
\hline Purchased feed costs $(\$)$ & 13,926 & 9,443 & 39,068 & 39,410 \\
\hline
\end{tabular}


Table 4. Implications of alternative federal graxing fee formulas on the economic viability of a representative sheep and cattle ranch in southeastern New Mexico.

\begin{tabular}{|c|c|c|c|c|c|}
\hline & $\begin{array}{l}\text { PRIA } \\
\text { formula }\end{array}$ & $\begin{array}{l}\text { Updated } \\
\text { PRIA }\end{array}$ & $\begin{array}{l}\text { Modified } \\
\text { PRIA }\end{array}$ & $\begin{array}{l}\text { Combined } \\
\text { value fee }\end{array}$ & $\begin{array}{l}\text { Modified } \\
\text { market value }\end{array}$ \\
\hline \multicolumn{6}{|l|}{ Probability of lower } \\
\hline real equity $(\%)$ & 100. & 100. & 100. & 100. & 100. \\
\hline \multicolumn{6}{|l|}{ Average change in real } \\
\hline net worth (\%) & -10.00 & -12 & -20 & -17 & -22 \\
\hline Ending equity ratio (fract.) & 0.93 & 0.91 & 0.83 & 0.86 & 0.80 \\
\hline \multicolumn{6}{|l|}{ Average annual cash } \\
\hline receipts $(\$ 1000)$ & 163.05 & 163.05 & 163.05 & 163.05 & 163.05 \\
\hline \multicolumn{6}{|l|}{ Average annual cash } \\
\hline expenses $(\$ 1000)$ & 127.32 & 131.06 & 150.18 & 144.87 & 155.68 \\
\hline \multicolumn{6}{|l|}{ Average annual net } \\
\hline cash income $(\$ 1000)$ & 35.73 & 31.99 & 12.87 & 18.18 & 7.37 \\
\hline \multicolumn{6}{|l|}{$\begin{array}{l}\text { Coefficient of variation } \\
\text { annual net cash }\end{array}$} \\
\hline income (\%) & 18. & 21. & 55. & 38. & 104. \\
\hline \multicolumn{6}{|l|}{ Risk index for annual } \\
\hline net cash income (\%) & 0. & 16. & 205. & 111 & 477. \\
\hline \multicolumn{6}{|c|}{ Average net cash income $(\$ 1000)$} \\
\hline 1992 & 47.12 & 43.93 & 27.65 & 32.12 & 26.32 \\
\hline 1993 & 39.01 & 35.38 & 18.08 & 22.83 & 14.13 \\
\hline 1994 & 33.11 & 28.87 & 10.23 & 15.36 & 4.75 \\
\hline 1995 & 32.93 & 29.23 & 10.28 & 15.46 & 3.21 \\
\hline 1996 & 30.95 & 27.65 & 7.90 & 13.55 & -0.43 \\
\hline 1997 & 31.28 & 26.90 & 3.09 & 9.74 & -3.79 \\
\hline
\end{tabular}

PRIA Formula $=\$ 1.23 *$ (FV164 + BCPI64 PPI64)/100 and minimum is $\$ 1.35 /$ AUM and maximum annual change is + or $-25 \%$.

Updated PRIA Formula + \$2.43* (FVI89* BCPI89/ICI89)/100.

Modified PRIA Fee System = \$5.45* (FVI89* BCPI89/1CI89)/100.

Combined Value Fee System $=\$ 4.62 *$ (FVI $89 *$ BCPI89/ICI89) $/ 100$

Modified Market Value Fee System $=\$ 5.45 *$ (FVI89) $/ 100$.

Probability of Lower Real Equity-Chance that the farm will experience a decrease in net worth after adjusting for inflation.

Change in Real Net Worth-Percentage change in real net worth over the simulation period, 1992-1997.

Ending Equity Ratio-Total net worth divided by total assets in the last year simulated.

Annual Cash Receipts-Total cash receipts from crops, dairy, livestock, government payments, and other farm related activities.

Annual Cash Receipts-Total cash receipts from crops, dairy, livestock, government payments, and other farm related activities.
Annual Cash Expenses-Total cash costs for crops, dairy, and livestock production, including interest costs and fixed cash costs; excludes depreciation

Annual Net Cash Income-Total cash receipts minus total cash expenses; excludes family living expenses, principal payments, and costs to replace capital assets.

The Southeastern Montana panel ranch located in Custer County has 483 animal units consisting of 400 cows, 58 replacement heifers, 18 bulls, 7 horses (Table 3). The panel ranch grazes 8,101 ha of rangeland, of which 1,823 ha are leased from the federal government, 5,670 are owned, and 608 ha are leased from private and state sources. Annual grazing on federal rangeland accounts for 112.5 AUs or about $23 \%$ of the ranch's grazing requirements. At a price of \$1.92/AUM, the federal grazing cost is \$2,592 annually on the panel ranch. The stocking rate of 12 ha per $A U$ is considered to be about the same as on private, federal, and state lands. Lease costs on private and state land averages about $\$ 2.50 / A U M$. The value of land and improvements on the panel ranch was estimated at $\$ 700,000$ by the panel. The value of cattle, excluding calves, was set at $\$ 341,900$ by valuing breeding stock at fall 1990 prices.

The Northwest Nevada cattle ranch located in Humboldt County has 1,740 AUs consisting of 1,450 cows, 200 replacement heifers, and 90 bulls (Table 3). The Northwest Nevada ranch grazes 284 ha of meadow hay, 1,661 ha of rangeland, and grows 405 ha of alfalfa on 2,349 deeded ha. The ranch has a spring and summer BLM lease of 842 AUs. Public grazing for this type of Nevada ranch frequently has a 6-month duration. Typically in a good grazing year, such range might yield an AUM per 4.9 ha. Thus a rancher might oversee livestock on 48,600 ha, which partially accounts for the high asset value.

\section{Results}

\section{Southeast New Mexico Sheep and Cattle Ranch}

Under the current formula, average annual net cash income is $\$ 35,730$ (Table 4). Net cash income steadily decreases from $\$ 47,120$ in 1992 to a low of $\$ 30,950$ in 1996 as beef prices decline due to the beef price cycle. A slight recovery in net cash income occurred in 1997 as beef cattle prices recover. The low net cash incomes result in a $100 \%$ probablity of reduced real net worth under the current formula. On average, the ranch experiences a $10 \%$ decline in its earned real net worth by 1997 . Comparing the 4 alternative grazing fee formulas to the current formula reveals average annual net cash income is lower for all 4 alternative grazing fee formulas. The largest reduction in average annual net cash income $(\$ 28,360)$ occurs under the Modified Market Value formula (\$5.21 average fee level) because this formula is associated with the largest increase in grazing fees. Risk, as measured by the coefficient of variation, associated with net cash income is lowest for the current formula. The Updated formula would increase net cash income variability $16 \%$ while the Modified formula increases income variability about $200 \%$. The Combined Value Fee System ( $\$ 4.05$ average fee) and Modified Market Value System (\$5.21 average fee) increase net cash income variability 111 and $477 \%$, respectively. Due to increased debt loads caused by lower net cash farm incomes, average net cash farm income does not increase in 1997 under the 4 alternative formulas as it does under the current formula.

Increased income risk and lower net incomes associated with the alternative formulas result in the ranch losing a much greater percent of its real net worth over the 6-year planning horizon than under the current formula. Under the Modified formula, or $\$ 4.78$ average fee level, the ranch would lose on average of $20 \%$ of its real net worth, or twice as much as under the current formula (Table 4). The Updated formula would reduce real net worth only 2 percentage points more than the current formula. 
Table 5. Implications of alternative federal grazing fee formulas on the economic viability of a representative shed lambing sheep ranch in Eastern Wyoming.

\begin{tabular}{|c|c|c|c|c|c|}
\hline & $\begin{array}{c}\text { PRIA } \\
\text { formula }\end{array}$ & $\begin{array}{l}\text { Updated } \\
\text { PRIA }\end{array}$ & $\begin{array}{l}\text { Modified } \\
\text { PRIA }\end{array}$ & $\begin{array}{l}\text { Combined } \\
\text { value fee }\end{array}$ & $\begin{array}{l}\text { Modified } \\
\text { market value }\end{array}$ \\
\hline $\begin{array}{l}\text { Probability of lower } \\
\text { real equity }(\%)\end{array}$ & 51. & 58. & 95. & 90. & 97. \\
\hline $\begin{array}{l}\text { Average change in } \\
\text { real net worth (\%) } \\
\text { Ending equity ratio (fract.) }\end{array}$ & $\begin{array}{l}0 . \\
0.96\end{array}$ & $\begin{array}{l}-1 \\
0.96\end{array}$ & $\begin{array}{l}-8 . \\
0.96\end{array}$ & $\begin{array}{l}-6 . \\
0.96\end{array}$ & $\begin{aligned}-10 . \\
0.94\end{aligned}$ \\
\hline $\begin{array}{l}\text { Average annual cash } \\
\text { receipts }(\$ 1000)\end{array}$ & 170.16 & 170.16 & 170.16 & 170.16 & 170.16 \\
\hline $\begin{array}{l}\text { Average annual cash } \\
\text { expenses }(\$ 1000) \\
\text { Average annual net cash }\end{array}$ & 108.57 & 111.58 & 126.53 & 122.26 & 131.15 \\
\hline $\begin{array}{l}\text { income }(\$ 1000) \\
\text { Coefficient of variation }\end{array}$ & 61.60 & 58.59 & 43.63 & 47.91 & 39.01 \\
\hline $\begin{array}{l}\text { annual net cash } \\
\text { income (\%) } \\
\text { Risk index for annual }\end{array}$ & 8. & 9. & 15. & 13. & 18. \\
\hline $\begin{array}{l}\text { Risk index for annual } \\
\text { net cash income (\%) }\end{array}$ & 0. & 12. & 88. & 62. & 125. \\
\hline $\begin{array}{l}\text { Average net cash income (\$1 } \\
1992 \\
1993 \\
1994 \\
1995 \\
1996 \\
1997\end{array}$ & $\begin{array}{l}66.40 \\
63.65 \\
58.60 \\
61.33 \\
59.90 \\
59.69\end{array}$ & $\begin{array}{l}62.93 \\
59.68 \\
54.85 \\
58.85 \\
57.85 \\
57.36\end{array}$ & $\begin{array}{l}47.64 \\
43.83 \\
38.51 \\
44.14 \\
44.14 \\
43.50\end{array}$ & $\begin{array}{l}51.84 \\
48.24 \\
43.13 \\
48.46 \\
48.22 \\
47.54\end{array}$ & $\begin{array}{l}46.12 \\
40.48 \\
33.71 \\
37.30 \\
37.91 \\
38.55\end{array}$ \\
\hline
\end{tabular}

PRIA Formula $=\$ 1.23 *($ FVI64 + BCPI64 PPI64) $/ 100$ and minimum is $\$ 1.35 / A U M$ and maximum annual change is + or $-25 \%$

Updated PRIA Formula + \$2.43* (FVI89* BCPI89/ICI89)/100.

Modified PRIA Fee System $=\$ 5.45 *$ (FVI89* BCPI89/ICI89) $/ 100$.

Combined Value Fee System $=\$ 4.62 *$ (FVI89* BCPI89/ICI89) $/ 100$.

Modified Market Value Fee System $=\$ 5.45 *($ FVI89) $/ 100$.

Probability of Lower Real Equity-Chance that the farm will experience a decrease in net worth after adjusting for inflation.

Change in Real Net Worth-Percentage change in real net worth over the simulation period, 1992-1997.

Ending Equity Ratio-Total net worth divided by total assets in the last year simulated.

Annual Cash Receipts-Total cash receipts from crops, dairy, livestock, government payments, and other farm related activities.

Annual Cash Expenses-Total cash costs for crops, dairy, and livestock production, including interest costs and fixed cash costs; excludes depreciation.

Annual Net Cash Income-Total cash receipts minus total cash expenses; excludes family living expenses, principal payments, and costs to replace capital assets.

\section{Eastern Wyoming Shed Lambing Ranch}

Under the current formula, annual net cash income is projected to average $\$ 61,600$ over the $1992-97$ planning horizon (Table 5). On average, real net worth was maintained over the 6-year planning horizon. Comparing the 4 alternative federal grazing fee formulas to the current formula reveals that average annual net cash income fell about $\$ 3,010$ if the Updated formula was adopted while the Modified Market Value formula reduces average annual net cash income by $\$ 22,590$. The variability in net income increased $12 \%$ under the Updated formula while the Modified Market Value formula increased income variability approximately $125 \%$. The 4 alternative grazing fee scenarios result in a decline in the ranch's earned real net worth over the period ranging from $1 \%$ under the Updated formula to $10 \%$ when utilizing the Modified Market Value formula. The probability that the ranch would experience a lower real net worth was $51 \%$ for the current formula but was increased to $90 \%$ or more for 3 of the 4 alternative formulas.

\section{Southeastern Montana Cattle Ranch}

Annual net cash income averaged \$53,000 over the 1992-97 planning horizon under the current formula (Table 6). For the base formula, net cash income declined from $\$ 60,360$ in 1992 to $\$ 45,940$ in 1995 and then increased through 1997 due to the change in cattle prices. Given the current formula, the ranch has a $99 \%$ probability of reducing its real earned equity (and on average, real net worth falls $9 \%$ by 1997 ) despite a net cash income of $\$ 53,000$ per year. The real loss in net worth results from cash flow deficits which are caused by family living expenses, principal payments, and capital asset replacement costs exceeding net cash income as cattle prices decline. Comparing the alterantive federal grazing fee formulas to the current formula reveals average annual net cash income falls by
$\$ 1,170$ to $\$ 9,370$ per year under the alternative grazing fee formulas. Variability of net cash income increases as much as $33 \%$ under the alternative grazing fee formulas, with the Updated formula increasing income variability the least and the Modified Market Value formula increasing income variability the most. The average loss in real net worth is not much greater than under the current formula because the alternative formulas do not reduce net cash income significantly and the ranch is relatively profitable.

\section{Northwest Nevada Cattle Ranch}

Under the current formula, annual net cash income averages about $\$ 179,730$ over 1992-97 (Table 7). Net cash income decreases from $\$ 197,480$ in 1992 to a low of $\$ 163,290$ in 1995 and then increases as beef cattle prices recover. With the current formula, despite relatively large net cash incomes, the ranch has a $59 \%$ chance of decreasing real net worth over the 6-year planning horizon because its principal payments, depreciation, and family living expenses exceed net cash income in most years. The average loss in real earned net worth is about $1 \%$ under the current formula. Comparing the alternative federal grazing fee formulas to the current formula reveals average annual net cash income would decline from $\$ 4,660$ to $\$ 35,990$ as federal grazing fees are increased under the alternative formulas. The largest decrease in net cash income results from the Modified Market Value formula (20\%) while the smallest decrease is associated with the Updated formula (2.5\%). Variability in net cash income would be about the same under the Modified but $11 \%$ less under the Updated formula. The Modified Market Value formula results in the greatest increase in relative variability (22\%). The Modified Market Value formula would have the greatest adverse impact on the ranch's ability to maintain real net worth; with the ranch projected to lose approxi- 
Table 6. Implications of alternative federal grazing fee formulas on the economic viability of a representative cattle ranch in southeastern Montana, 23\% federal grazing.

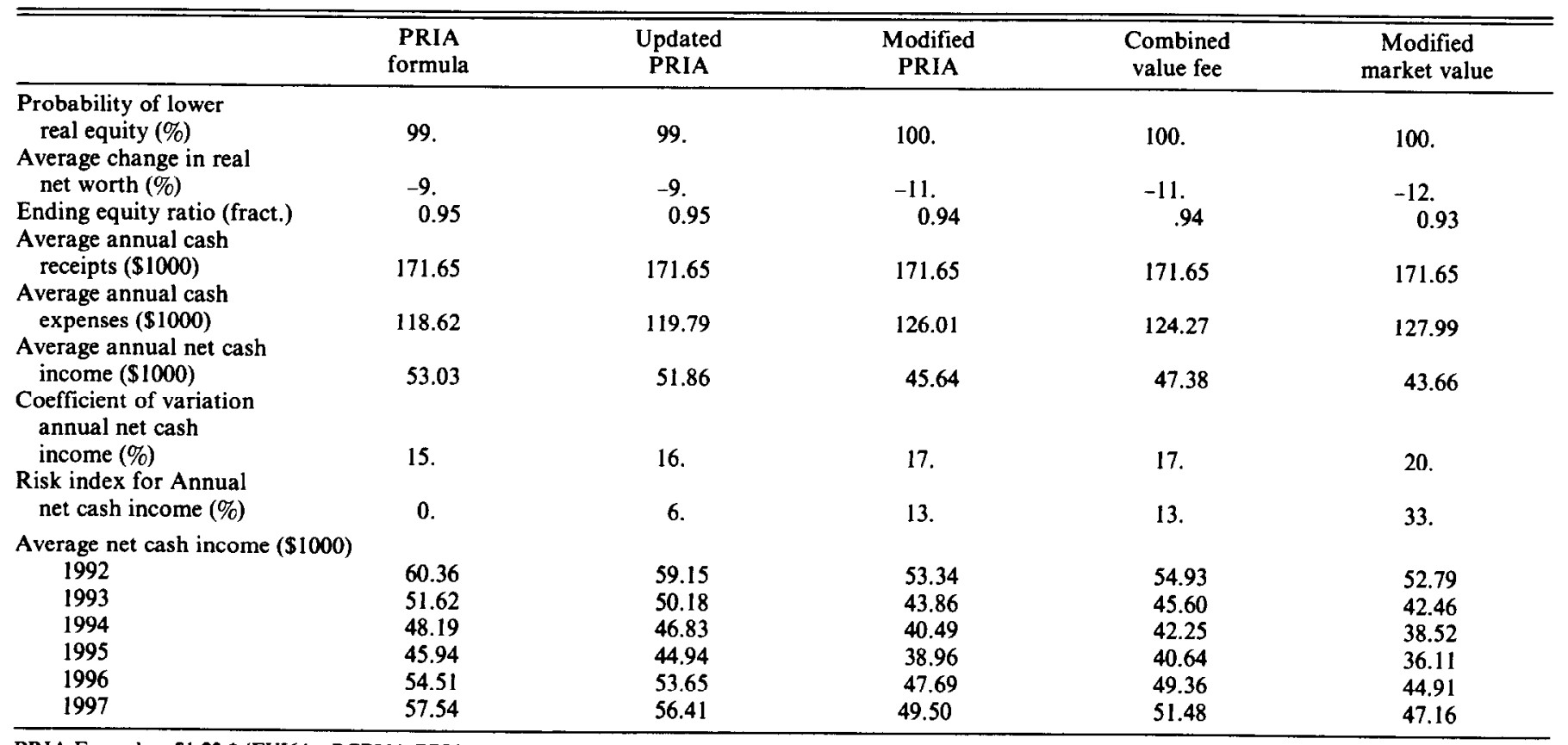

PRIA Formula $=\$ 1.23 *($ FVI64 + BCPI64 PPI64) $/ 100$ and minimum is $\$ 1.35 /$ AUM and maximum annual change is + or $-25 \%$

Updated PRIA Formula +\$2.43* (FVI89* BCPI89/ICI89)/ 100 .

Modified PRIA Fee System $=\$ 5.45 *$ (FVI89* BCPI89/ICI89) $/ 100$

Combined Value Fee System $=\$ 4.62 *($ FVI89* BCPI89/ICI89) $/ 100$

Modified Market Value Fee System $=\$ 5.45 *($ FVI89) $/ 100$

Probability of Lower Real Equity-Chance that the farm will experience a decrease in net worth after adjusting for inflation.

Change in Real Net Worth-Percentage change in real net worth over the simulation period, 1992-1997.

Ending Equity Ratio-Total net worth divided by total assets in the last year simulated.

Annual Cash Receipts-Total cash receipts from crops, dairy, livestock, government payments, and other farm related activities.

Annual Cash Expenses-Total cash costs for crops, dairy, and livestock production, including interest costs and fixed cash costs; excludes depreciation.

Annual Net Cash Income-Total cash receipts minus total cash expenses; excludes family living expenses, principal payments, and costs to replace capital assets.

mately $6 \%$ of its real equity by 1997 .

\section{Summary and Implications}

The purpose of this study was to quantify the impacts of alternative federal grazing fee formulas on the economic viability (level of income and risk) of 4 representative ranches leasing public range lands in the Western United States. The Farm Level Income Tax and Policy Simulation Model was used to simulate the probable consequences of 4 alternative grazing fee formulas for a variety of ranches in major public land regions of the United States. The formulas analyzed were the current Public Rangeland Improvement, Updated, Modified Fee System, Combined Value Fee System, and Modified Market Value Fee System.

Average annual net cash income is projected to remain positive but decline over the first 4 years of the planning horizon as cattle prices weaken. Increasing cattle prices increase average annual net cash farm income in 1996 and 1997 for ranches which do not amass significant debts while cattle prices are low. Average annual net cash incomes decrease by as much as $22 \%$, relative to the current formula, under alternative grazing fee formulas. Additionally, the results suggest that the alternative grazing fee formulas would increase income risk as measured by the coefficient of variation of net cash income by up to $477 \%$.

The results of this analysis suggest that as cattle prices decline over the 1992-1996 period western ranches will experience financial pressures that lower grazing fees under PRIA will not alleviate. Alternative grazing fee formulas do not decrease sufficiently due to lower cattle prices to maintain ranch incomes. The beef cattle cycle has started a down turn in prices as the market reacts to increased supplies. This biological/economic relationship will result in lower prices until cattle numbers decline. A change in economic forces (i.e., a new administration) will not likely be able to expand beef demand sufficiently to overcome the adverse effects of the cattle cycle on ranch incomes.

In conclusion, the present study quantifies the amount that alternative federal grazing fees would reduce the economic viability of ranches who lease federal rangeland. Economic viability would be reduced by decreasing net cash income, increasing the risk on net income, and reducing net worth. If the ability to pay and the economic viability of ranchers and rural communities in the West are criteria for setting federal grazing fees, further research into the matter is needed before the federal grazing fee formula is changed.

\section{Literature Cited}

Duffy, P.A., J.W. Richardson, and E.G. Smith. 1986. The effects of alternative farm programs and levels of price variability on Texas cotton farms. S.J. of Agr. Econ. 18:97-106.

Dutton, W.L. 1953. History of Forest Service grazing fees. J. Range Manage. 6:393-398.

Food and Agricultural Policy Research Institute (FAPRI). 1992. FAPRI 1992 U.S. agricultural outlook. Univ. Missouri-Columbia and Iowa State Univ., Staff Rep. \#1-92.

Grant, W.R., J.W. Richardson, B.W. Brorsen, and M.E. Rister. 1984. Economic impact of increased price variability: a case study with rice. Agr. Econ. Res. 36:17-27. 
Table 7. Implications of alternative federal grazing fee formulas on the economic viability of a representative cattle ranch in northwestern Nevada.

\begin{tabular}{|c|c|c|c|c|c|}
\hline & $\begin{array}{c}\text { PRIA } \\
\text { formula }\end{array}$ & $\begin{array}{l}\text { Updated } \\
\text { PRIA }\end{array}$ & $\begin{array}{l}\text { Modified } \\
\text { PRIA }\end{array}$ & $\begin{array}{l}\text { Combined } \\
\text { value fee }\end{array}$ & $\begin{array}{l}\text { Modified } \\
\text { market value }\end{array}$ \\
\hline $\begin{array}{l}\text { Probability of lower } \\
\text { real equity }(\%)\end{array}$ & 59. & 71. & 94. & 90. & 95. \\
\hline $\begin{array}{l}\text { Average change in } \\
\text { real net worth }(\%)\end{array}$ & -1 & -1 & -5 & -4. & -6 \\
\hline $\begin{array}{l}\text { Ending equity } \\
\text { ratio (fract.) }\end{array}$ & 0.97 & 0.97 & 0.97 & 0.97 & 0.97 \\
\hline $\begin{array}{l}\text { Average annual cash } \\
\text { receipts }(\$ 1000)\end{array}$ & 448.93 & 448.93 & 448.93 & 448.93 & 448.93 \\
\hline $\begin{array}{l}\text { Average annual cash } \\
\text { expenses }(\$ 1000)\end{array}$ & 269.21 & 273.87 & 297.74 & 291.15 & 305.20 \\
\hline $\begin{array}{l}\text { Average annual net cash } \\
\text { income }(\$ 1000)\end{array}$ & 179.73 & 175.07 & 151.20 & 157.78 & 143.74 \\
\hline $\begin{array}{l}\text { Coefficient of variation } \\
\text { annual net cash } \\
\text { income (\%) }\end{array}$ & 9. & 8. & 9. & 9. & 11. \\
\hline $\begin{array}{l}\text { Risk index for annual } \\
\text { net cash income (\%) }\end{array}$ & 0. & -11 & 0. & 0. & 22. \\
\hline $\begin{array}{l}\text { Average net cash income } \\
1992 \\
1993 \\
1994 \\
1995 \\
1996 \\
1997\end{array}$ & $\begin{array}{l}197.48 \\
179.46 \\
166.87 \\
163.29 \\
179.61 \\
191.64\end{array}$ & $\begin{array}{l}192.14 \\
174.10 \\
160.96 \\
159.08 \\
176.21 \\
187.90\end{array}$ & $\begin{array}{l}166.02 \\
147.36 \\
135.76 \\
136.80 \\
155.00 \\
166.23\end{array}$ & $\begin{array}{l}173.20 \\
154.76 \\
142.78 \\
142.93 \\
160.83 \\
172.18\end{array}$ & $\begin{array}{l}163.45 \\
139.94 \\
128.22 \\
126.19 \\
145.50 \\
159.12\end{array}$ \\
\hline
\end{tabular}

PRIA Formula $=\$ 1.23 *($ FVI64 + BCPI64 PPI64)/100 and minimum is $\$ 1.35 /$ AUM and maximum annual change is + or $-25 \%$

Updated PRIA Formula $+\$ 2.43 *$ (FVI89* BCPI89/ICI89)/100

Modified PRIA Fee System $=\$ 5.45 *$ (FVI89* BCPI89/ICI89) $/ 100$

Modified PRIA Fee System $=\$ 5.45 *($ FVI89* BCPI89/ICI89) $/ 100$.
Combined Value Fee System $=\$ 4.62 *($ FVI89* BCPI89/ICI89) $/ 100$

Modified Market Value Fee System $=\$ 5.45 *($ FVI89) $/ 100$

Probability of Lower Real Equity-Chance that the farm will experience a decrease in net worth after adjustint for inflation.

Change in Real Net Worth-Percentage change in real net worth over the simulation period, 1992-1997.

Ending Equity Ratio-Total net worth divided by total assets in the last year simulated.

Annual Cash Receipts-Total cash receipts from crops, dairy, livestock, government payments, and other farm related activities.

Annual Cash Expenses-Total cash costs for crops, dairy, and livestock production, including interest costs and fixed cash costs; excludes depreciation.

Annual Cash Expenses-Total cash costs for crops, dairy, and livestock production, family living expenses, principal payments, and costs to replace capital assets.

Knutson, R.D., J.W. Richardson, E.G. Smith, D.P. Anderson, T.R. Harris, W.O. Champney, A.B. Marshall, and T.R. MacDiarmid. 1992. Economic impacts of alternative grazing fees on selected representative ranches and rural communities in the western states. Agricultural and Food Policy Center working paper 92-6. Dep. Agr. Econ. Texas A\&M Univ.

Lemieux, C.M., and J.W. Richardson. 1989. Economic impacts of Porcine Somatotropin on midwest hog producers. North Central J. of Agr. Econ. 11:171-182.

Penson, John B., Jr., E.G. Smith, J. Davis. 1992. "Modeling crop supply in AG-GEM," presented at ASCS Seminar, USDA, Washington, D.C.

Richardson, J.W., and C.J. Nixon. 1982. Producer's preference for a cotton farmer owned reserve: an application of simulation and stochastic dominance. West J. of Agr. Econ. 7:123-132.

Richardson, J.W., and C.J. Nixon. 1984. Effects of the 1980, 1981, and 1982 tax laws on Texas rice farmers. S.J. of Agr. Econ. 16:137-144.

Richardson, J.W., and C.J. Nixon. 1986. Description of FLIPSIM V: a general firm level policy simulation model. Texas Agr. Exp. Sta. Bull. B-1528.
Richardson, J.W., and E.G. Smith. 1985. Impacts of farm policies and technology on the economic viability of Texas southern high plains wheat farms. Texas Agr. Exp. Sta. Bull., B-1506.

Smith, E.G., J.W. Richardson, and R. Knutson. 1985. Impact of alternative farm programs on different size cotton farms in the Texas southern high plains: a simulation approach. W.J. of Agr. Econ. 10:365-374.

U.S. Congress, Office of Technology Assessment. 1986. Technology, public policy, and the changing structure of American agriculture. OTA-F-285. Washington, D.C. U.S. Gov. Print. Off.

U.S. Department of Agriculture and U.S. Department of Interior. 1986. Grazing fee review and evaluation. A report from the Secretary of Agriculture and the Secretary of the Interior.

U.S. Department of Interior, Bureau of Land Management. 1991. Public Land Statistics.

U.S. General Accounting Office. 1991. Rangeland management: current formula keeps grazing fees low. GAO/RCED-19-185BR. 